\title{
Analysis of Variability of the Black Sea Hydrophysical Fields in 1993-2012 Based on the Reanalysis Results
}

\author{
V.L. Dorofeev, L.I. Sukhikh \\ Marine Hydrophysical Institute, Russian Academy of Sciences, Sevastopol, Russian Federation \\ e-mail: l.sukhikh@gmail.com
}

\begin{abstract}
The work is devoted to the study of the long-term (1993-2012) variability of the Black Sea dynamics. The basis of the presented analysis is hydrophysical fields. They were resulted from physical reanalysis carried out based on remote sensing data assimilation in the numerical model of the Black Sea circulation. As boundary conditions on the free surface the model uses ERA-Interim atmospheric forcing. Availability of three-dimensional hydrophysical arrays on a regular grid permits to quantify the impact of various physical processes on formation of thermohaline structure and circulation of the Black Sea waters. It is shown that during the considered period the sub-surface layer temperature and salinity grow. It is manifested in increase of the sea surface temperature and degradation of the cold intermediate layer. Impact of winter thermal convection and water advection from the north-western shelf upon renewal of the cold intermediate layer waters is quantitatively assessed. Evolution of the upper mixed layer thickness which is of a well pronounced seasonal character is represented. It is shown that formation of a horizontal circulation is conditioned mainly by the wind field vorticity over the Black Sea. It is revealed that a crucial contribution to formation of a vertical circulation cell in the Black Sea is done by the wind field.
\end{abstract}

Keywords: reanalysis, the Black Sea dynamics, data assimilation, cold intermediate layer.

DOI: 10.22449/1573-160X-2016-1-33-47

(C) 2016, V.L. Dorofeev, L.I. Sukhikh

(C) 2016, Physical Oceanography

\section{Introduction}

To study the changes of various time scales taking place in the marine systems the method of reanalysis carried out based on remote sensing data assimilation in the numerical models has currently become widespread. And besides, both physical and biogeochemical systems can be taken into consideration. This method was first applied in studying of the physical process in the atmosphere. Presently there is a large set of atmospheric reanalyzes. With regard to simulation of the sea and ocean circulation the results of atmospheric reanalyzes are often used to set the boundary conditions on the sea surface. Reanalysis of the seas and ocean hydrophysical fields were performed later. For the Black Sea several variants of the retrospective physical analysis were carried out. In [1 - 3] on the basis of different models of the Black Sea circulation and temperature and salinity measurement data, the hydrophysical arrays on a regular grid were obtained.

The Black Sea isolation from the World Ocean is its peculiarity. It is almost closed and connects the Mediterranean Sea by the chain of narrow straits. Due to this isolation the Black Sea has its unique marine ecosystem, which, according to long-term measurements, has undergone significant changes during the last decades of the last century. The physical reanalysis for a long period (from 1971 to the beginning of the 1990s), which covers the time of the Black Sea ecosystem transformations, was performed in [2]. This period was selected due to the fact that at that time the maximum number of large-scale hydrological surveys was PHYSICAL OCEANOGRAPHY NO. 1 (2016) 
conducted in the Black Sea. The arrays of the current velocity and temperature fields calculated in this work were then used to simulate the evolution of the marine ecosystem [4]. The article [5] presents some results of the physical reanalysis carried out on the basis of the same hydrodynamic model that was used in [2], but for 1992 - 2002 period. In this work, in contrast to the papers mentioned above, the data of satellite altimetry measurements were assimilated. The hydrophysical fields derived were then used to simulate evolution of the Black Sea lower trophic level ecosystem [5].

In the present work the analysis of the Black Sea hydrophysical fields resulted from the assimilation of remote sensing data of the sea surface temperature and sea surface height in the circulation model for 1993 - 2012 period is carried out. As opposed to [5], in the calculation of the fields analyzed the Black Sea circulation model in the $z$-coordinates with a higher spatial resolution was applied. The remote sensing data were selected as there were only few hydrological surveys within the considered time period and they were mainly conducted in the coastal area. At the same time satellite data of the sea surface temperature and sea level anomalies became available on a regular basis. These data and existing assimilation techniques were used to carry out the reanalysis.

\section{Reanalysis scheme}

Reanalysis was performed using a numerical hydrodynamic model adapted for the given basin, the measurement data and algorithms of their assimilation in the model. To obtain the hydrophysical fields analyzed in this paper, the Black Sea circulation model created in Marine Hydrophysical Institute [6], based on an approximation of the system of primitive ocean dynamics equations, was chosen to be the base one. At first this model was used to describe the climatic variability of dynamic characteristics of the basin. Then it was modified and applied in the Black Sea hydrophysical field nowcasting/forecasting operating system [7].

To carry out the reanalysis the version of the model with a grid step of $4.8 \mathrm{~km}$ was used, which made it possible to describe adequately the synoptic processes, as the Rossby deformation radius of the first baroclinic mode in the deep part of the Black Sea was about $25 \mathrm{~km}$. Model has 35 grid levels compressed to the sea surface. Vertical turbulent diffusion and viscosity are parameterized using the coefficients depending on the depth and time. The time dependence of the turbulent exchange coefficient has a climatic character, i.e. they are changing during the annual cycle.

The peculiarity of the circulation model applied is parameterization of penetrating shortwave radiation absorption by means of the bio-optical model [8]. Distribution of this part of the radiation in the sea upper layer is described by the following dependence

$$
\begin{gathered}
\operatorname{PAR}(x, y, z, t)=\operatorname{PAR}(x, y, 0, t) \times \\
\times\left\{R(x, y, t) \exp \left[-z / a_{1}(x, y, t)+(1-R(x, y, t))\right] \exp \left[-z / a_{2}(x, y, t)\right]\right\},
\end{gathered}
$$

where $R, a_{1}, a_{2}$ are the coefficients calculated on the basis of satellite data and depending on the spatial coordinates and time. During the simulation we used 
climatic (monthly averaged) values of these parameters similar to those that were used to describe the photosynthesis processes in the Black Sea ecosystem model.

The atmospheric parameters obtained as a result of ERA-Interim (ECMWF) atmospheric reanalysis were chosen as the boundary conditions on the sea surface for circulation model equations: the near-surface wind, heat fluxes and fresh water flows and the solar radiation. The average monthly climatic values of the runoff were set in estuaries and straits.

As it was noted above the important component in the reanalysis is the assimilation of the measurement data. In this work the sea surface temperature data, anomalies of the sea surface height and the average annual temperature and salinity profiles were assimilated. The values of the sea surface temperature were taken from GHRSST and NODC archives (1993 - 2009) and for the last period (2010 - 2012) - from OSI TAC archive. Within the reanalysis period we used all the available satellite altimetry data (NASA, AVISO and SL TAC archives). Annualmean temperature and salinity profiles were prepared on the basis of in-situ data from floating buoys and hydrographic surveys.

The sea surface temperature assimilation procedure used is similar to the one described in [7]. Every day for the grid points of the model, where there is data, the measured values of the surface temperature are compared with the model ones. Then, the sources, proportional to the difference between measured and model values of temperature, are added in the right hand side of the heat transportdiffusion equation in the measurement points on the horizons of the model within the upper mixed layer.

For the assimilation of satellite altimetry data the algorithm described in [9] was used. Briefly it boils down to the following: the temperature and salinity profiles at each point are corrected proportionally to the difference between the measured value of the sea surface height and the model one. The weight coefficients which depend on the depth are calculated by the cross-covariance functions of the level and salinity and/or temperature errors.

Average in-depth values of temperature and salinity were corrected at the horizons below $200 \mathrm{~m}$ and in accordance with the annual-mean profiles obtained from in-situ data, which the climate seasonal cycle was put on for.

\section{Analysis of the results obtained}

Thermohaline structure. Data of the performed reanalysis are the threedimensional hydrophysical arrays of the velocity currents, temperature and salinity fields on a regular grid calculated by time discreteness of 1 day. Modeling period was 20 years $(1993-2012)$.

We are to start the analysis of the evolution of the Black Sea hydrophysical fields based on the reanalysis results with the sea surface temperature. Fig. 1 shows the deviations of annual-mean and winter-mean Black Sea surface temperature values, averaged over the basin area. The deviations were calculated from the average values within 20 years, which accounted $14.95{ }^{\circ} \mathrm{C}$ for the whole year and $7.7^{\circ} \mathrm{C}$ for the winter. During the considered period there is a tendency of the increase of the both annual-mean and winter-mean temperatures. In the first half of the period the temperature anomalies are mainly negative, and in the second one positive.

PHYSICAL OCEANOGRAPHY NO. 1 (2016) 


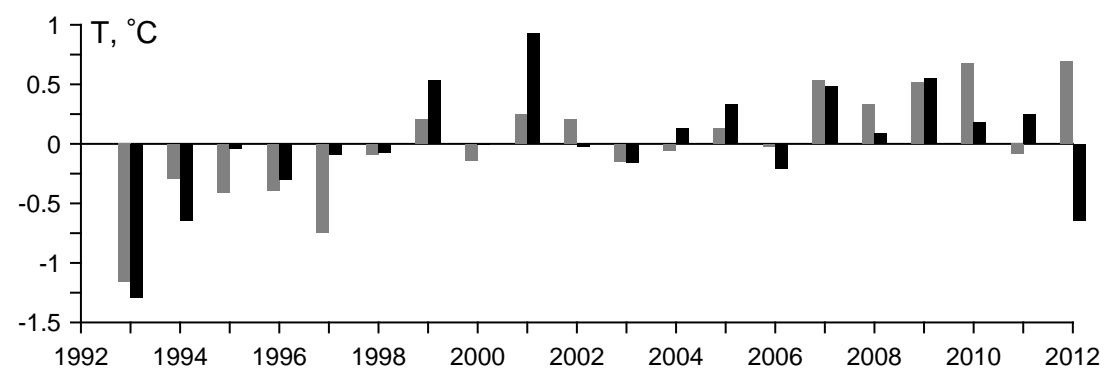

Fig. 1. The diagram of the variations of deviations of the annual-mean (gray bars) and the wintermean (black bars) values of surface temperature (deviations were calculated from the 20 year average values of 14.95 and $7.7^{\circ} \mathrm{C}$, respectively)

Heating of the Black Sea upper layer can be observed from the behavior of the monthly-averaged temperature within upper $200 \mathrm{~m}$ layer column of the sea (Fig. 2). Areas containing cold water at a temperature below $8{ }^{\circ} \mathrm{C}$ in the figure are marked with a dark color. In winter, the upper boundary of the cold layer of water reaches the surface. When the surface layer temperature warms above $8{ }^{\circ} \mathrm{C}$ (spring autumn), the diagram clearly identifies the cores of the cold intermediate layer (CIL). It can be seen that the area of the region with cold water decreases with time, which indicates the general warming of the Black Sea surface waters. Another indicator of the temperature increase is reducing of the depth of the $8.5^{\circ} \mathrm{C}$ lower isotherm.

The cold intermediate layer, limited on the top and bottom by the $8{ }^{\circ} \mathrm{C}$ isotherms is considered to be one of the main characteristics of vertical hydrological structure of the Black Sea. As a rule, the CIL, as a result of the winter cooling and subsequent warming of the sea surface, is maintained throughout the year. However, as it can be seen in Fig. 2, in some years the CIL is expressed very weakly. In order to quantify the CIL power, consider its average thickness and cold content, which is defined as the integral deviation of the water temperature of $8{ }^{\circ} \mathrm{C}$ : $\int_{h_{1}}^{h_{2}}\left(8^{\circ} \mathrm{C}-T\right) d z$ where $h_{1}, h_{2}$ are isothermal surfaces of both the space and time functions.

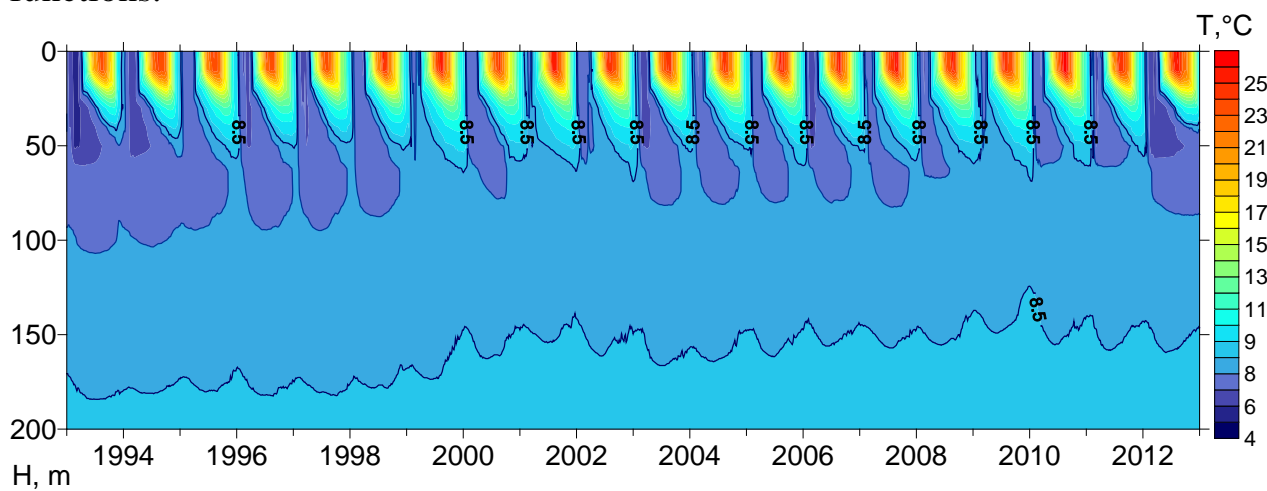

Fig. 2. Time evolution of the basin-averaged monthly-mean temperature within upper 200-m layer column 
It is known that the Black Sea CIL water renewal takes place in winter due to thermal convection in the deep part of the basin and lowering of the cold waters from the north-western shelf along the western coast [10 - 13]. Therefore CIL power throughout the year is formed mainly during the winter season. Fig. 3 shows graphs of the summer-mean CIL characteristics (cold content and thickness) for different years, as well as the winter-mean values of the surface temperature.

As follows from the graphs in Fig. 3, the summer-mean values of the CIL thickness and its cold content distinctly vary from year to year. In the considered time interval the CIL thickness values in various years can differ considerably, and the cold content values - even more. The latter is due to the fact that in the warm years not only the CIL thickness is small, but the temperature in it is high enough (close to $8{ }^{\circ} \mathrm{C}$ ). Another feature that can be seen from these graphs is a good correlation between the maxima of the winter surface temperature and minima of the CIL characteristics and vice versa. As an example, Fig. 4 shows the zonal sections of the summer-mean temperature of the Black Sea for eight years: the upper row corresponds to the years when, according to the graphs in Fig. 3, the CIL characteristics have small quantities, and the bottom row - to the summer seasons with a considerably powerful CIL.
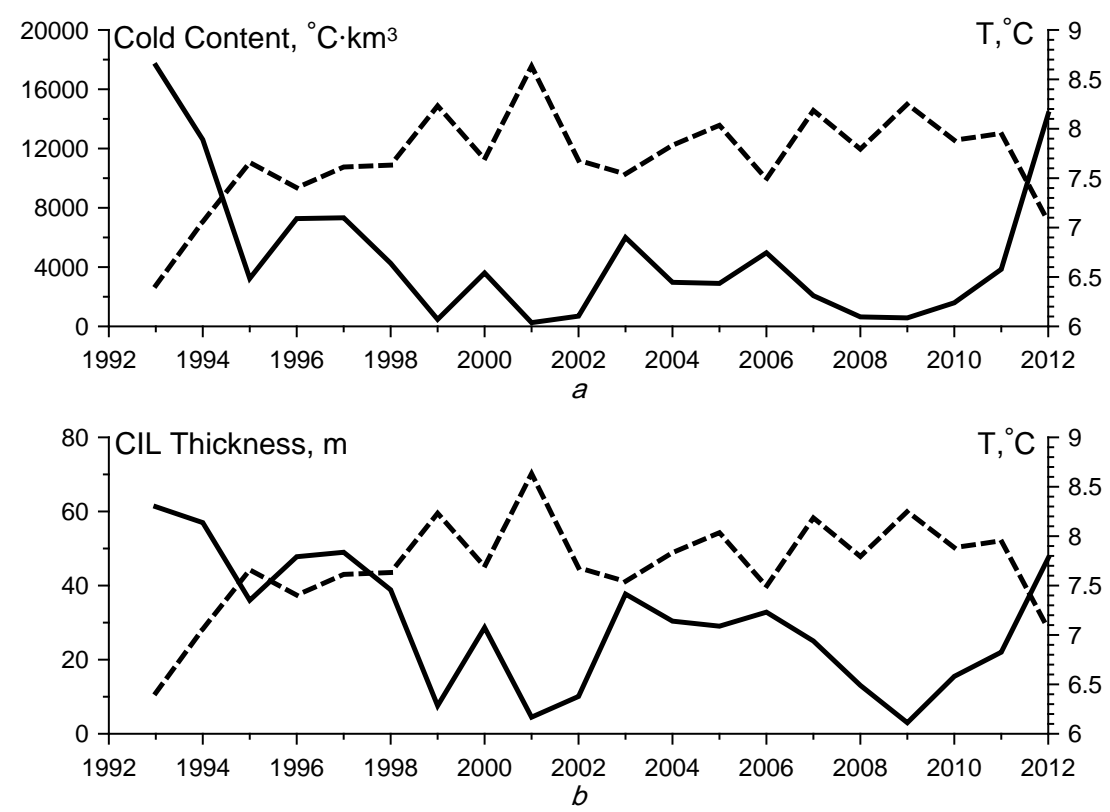

Fig. 3. The graphs of the variation of the annual-mean CIL cold content values (a) and its thickness (b) according to the reanalysis results (dashed lines show the change of the winter-mean sea surface temperature)

As it have been mentioned above, the renewal of water in the CIL takes place mainly in the winter season due to the processes of thermal convection in the central part of the sea and the advection of cold waters from the north-western shelf. In order to quantify the contribution of each of these processes in the CIL formation, similarly to the cold content, we are to introduce the concept of "cold PHYSICAL OCEANOGRAPHY NO. 1 (2016) 
flow" ( $\left(8{ }^{\circ} \mathrm{C}-T\right) V_{n}$, where $V_{n}$ is a normal velocity to the respective surface) and to calculate the value of the flow through the top and a lateral surface of the cylinder bounded by $200 \mathrm{~m}$ isobath and 35 and $105 \mathrm{~m}$ horizontal levels. The CIL is mainly concentrated in this sea layer. As for the lateral surface, we do not select it totally, only the part along the north-west and west coast of the Black Sea. Then we integrate the calculated values according to time per each year, taking into account only incoming flows. Thus, we estimate the cold content value in the layer for the winter-spring season for each of the two processes.

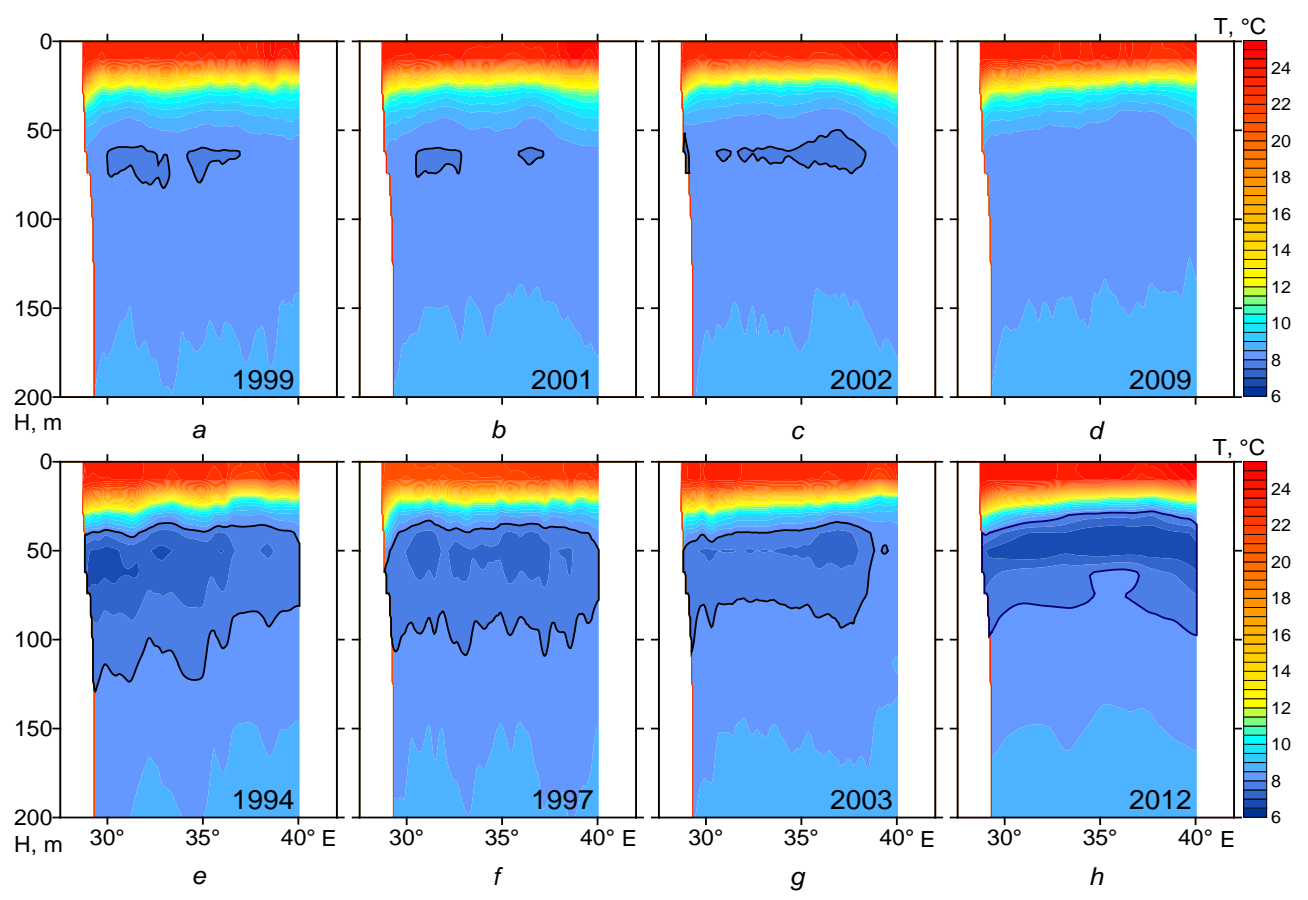

Fig. 4. Zonal section of the summer-mean temperature along $43.5^{\circ} \mathrm{N}$ latitude

Fig. 5, $a$ shows the values obtained for each year of the considered period. It is seen that, firstly, the "cold" amount entering this layer varies from year to year. Secondly, the increase of the cold content for the account of thermal convection in the deep part of the sea is, as a rule, greater (2 times on average) than for the account of cold waters descending from the north-western shelf. In some years, the effect of thermal convection in the central part of the sea and the advection of cold water from the north-western shelf are about the same and even lower in 2007. Fig. 5, $b$ presents the graphs of the total entrance of "cold" in the considered layer (the sum of the values given in Fig. 5, $a$ ) and the annual-mean cold content values calculated directly for the CIL (between the $8{ }^{\circ} \mathrm{C}$ isothermal surfaces). Both curves follow one another well. According to these graphs, we can conclude that the proposed method of assessing the contribution of the two processes in the formation of the CIL adequately reflects the reality. 

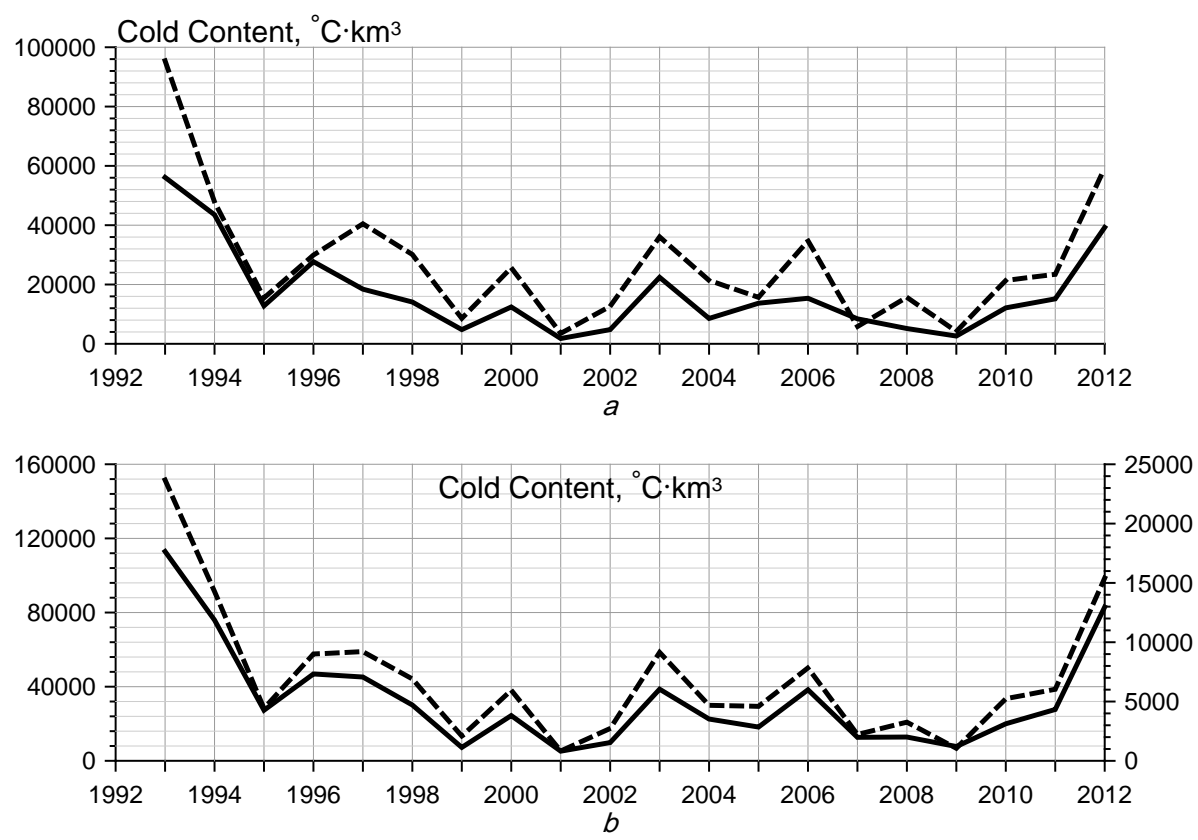

Fig. 5. The cold content values in $35-105$ m layer, obtained within a year through the upper (dashed line) and lateral (solid line) boundary, $-a$, and also its total values (dashed line, the y-axis on the left) and the annual-mean cold content values of the CIL (solid line, the $y$-axis on the right) $-b$

Another parameter characterizing the thermohaline structure of the Black Sea waters is the salinity. Fig. 6 shows the evolution of the basin-averaged monthlymean salinity in the upper $200 \mathrm{~m}$ layer of the sea. The seasonal variation of salinity is clearly seen up to a depth of approximately $50 \mathrm{~m}$. The minimum values of the surface waters salinity are observed in the early summer after the spring flood of the rivers flowing into the Black Sea. Thereafter salinity value starts to increase and reaches its maximum in the early winter. The interannual variability of salinity values in the near-surface layer can also be traced. In general, in the upper $200 \mathrm{~m}$ layer the average salinity value increases that can be observed by the $20 \%$ salinity isoline rising and especially by $21 \%$ isoline.

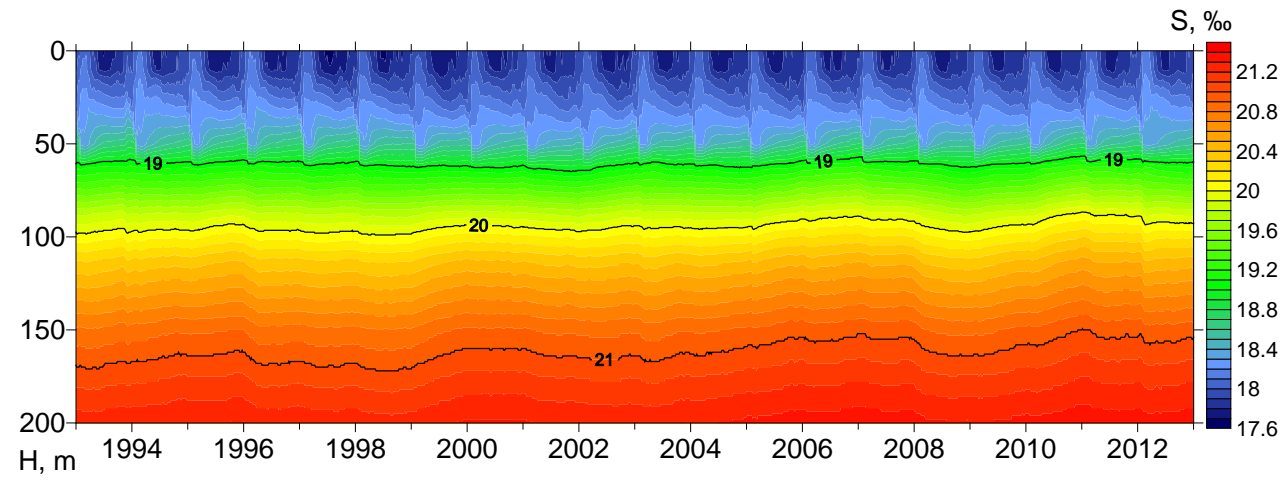

Fig. 6. Temporal evolution of the basin-averaged monthly-mean values of salinity in the upper 200-m layer

PHYSICAL OCEANOGRAPHY NO. 1 (2016) 
Maps of the spatial distribution of the salinity values within the near-surface layer are shown in Fig. 7. They show climatic values computed during the considered 20-year period for February, April, June, and November. On all the maps the maximum salinity values are observed in the central part of the Black Sea. Waters with the minimum salinity values are located in the north-western shelf, and to the south along the west coast, which is due to the Danube run-off, providing a maximum fresh water flow into the sea. On the maps above we can see that the maximum salinity values are observed in February, and the lowest ones in June.

The upper mixed layer (UML), associated mainly with the processes of wind mixing and heat flows through the sea surface, is an important component in the vertical hydrological structure of the Black Sea. The depth of the mixed layer reaches its greatest values in the winter, when in the Black Sea there are storms and thermal convection occurs upon the surface water cooling.

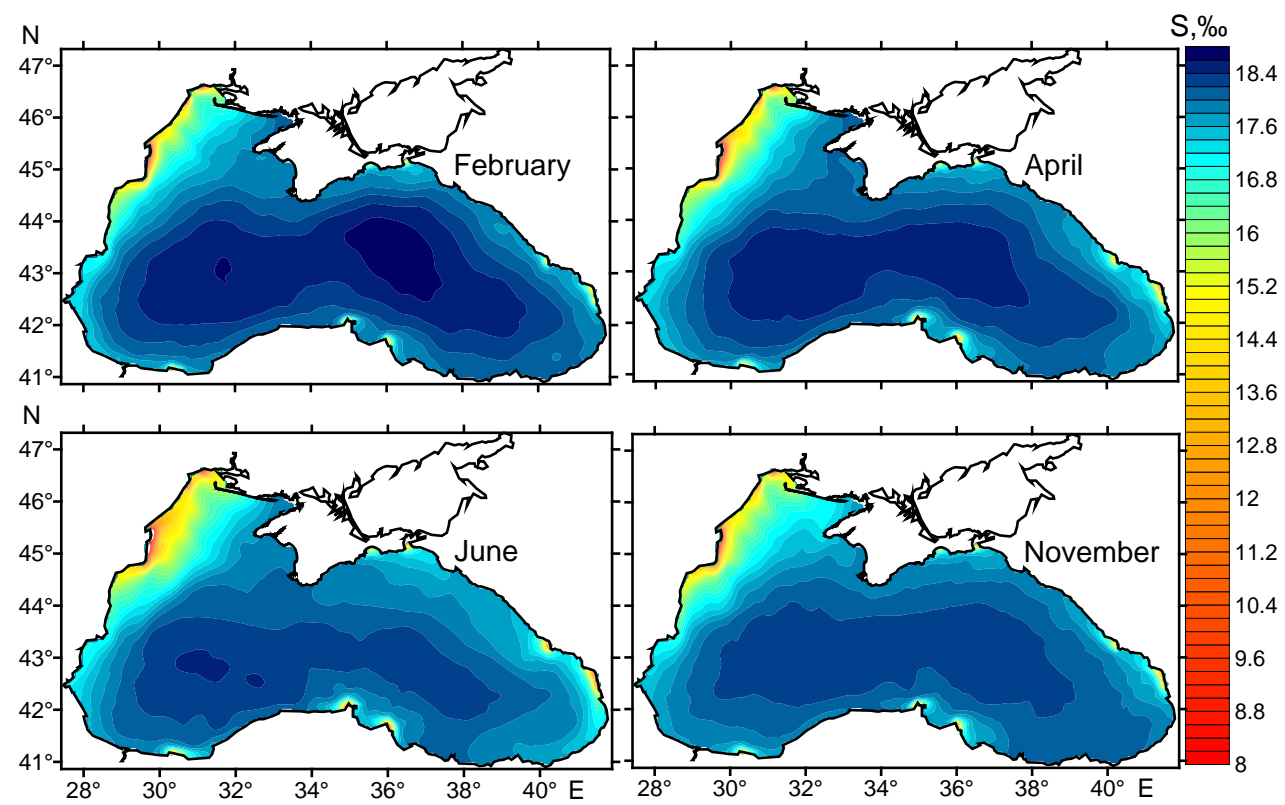

Fig. 7. Maps of the spatial distribution of the salinity values within the near-surface layer in February, April, June and November

Fig. 8, $a$ demonstrates a temporal evolution of the UML thickness averaged over the deep part of the basin. At each point the depth of the lower UML boundary was defined as the last boundary layer where the water density was different from the surface one less than $0.2 \mathrm{~kg} / \mathrm{m}^{3}$. Change in the mean UML thickness is highly seasonal. It varies from $\approx 50 \mathrm{~m}$ value in the winter to $5 \mathrm{~m}$ one in the summer. Fig. 8 , $b$ shows the mean UML thickness values for the winter for various years. During the considered period the winter-mean UML thickness values varied from 36 to $40 \mathrm{~m}$. The maximum UML thickness in the winter was observed in 2002 and 2009. 

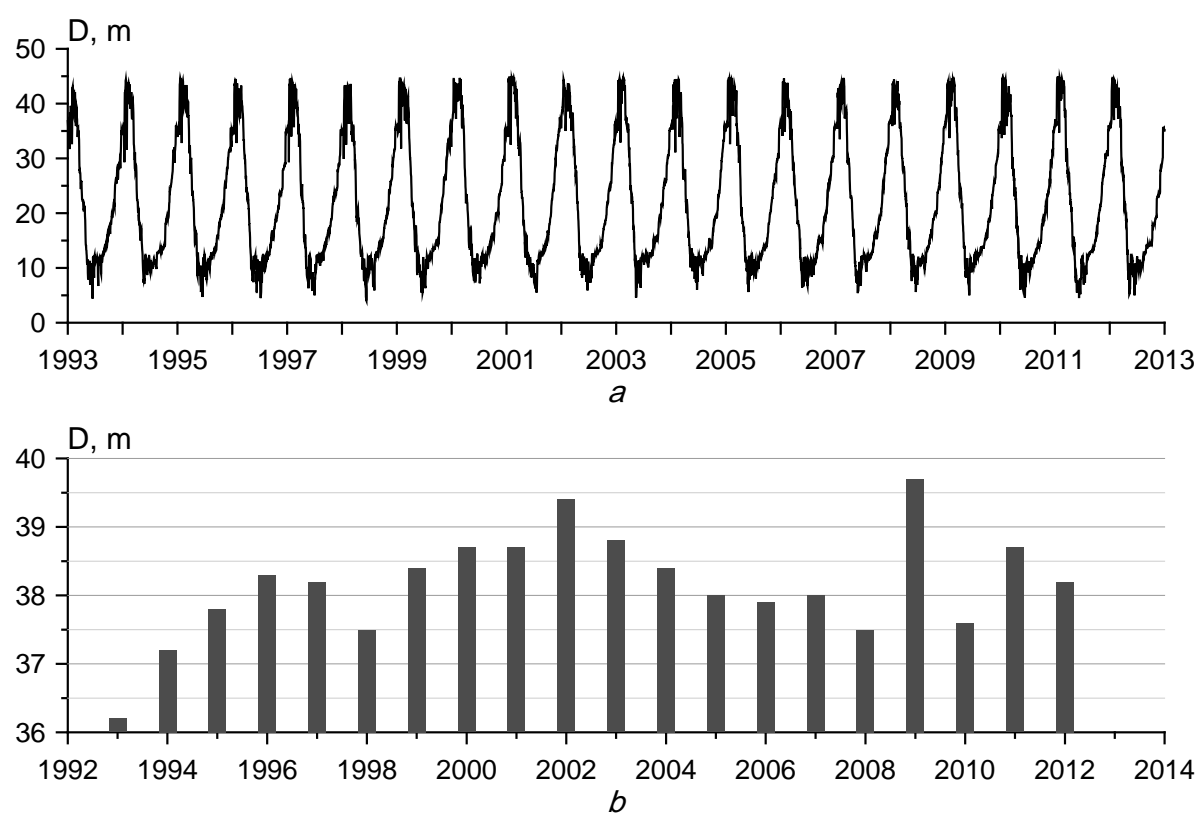

Fig. 8. Time dependence of the mean UML thickness $D$ for the deep part of the basin $(a)$, and also annual-mean values of the UML thickness $(b)$

Circulation. Below we are to consider the currents in the sea upper layer and their variability. It is known that the circulation in the upper layers of the Black Sea is of mainly cyclonic character [14], which is determined by the predominance of positive values of the vertical component of the vorticity of the wind field over the region. The most pronounced feature of the circulation in the upper layer is the Black Sea Rim Current. It encircles the perimeter of the Black Sea and forms a large-scale cyclonic gyre. In the western and eastern parts of the basin in winter the main gyre is divided into two smaller ones. Thus, the scheme of currents in winter represents two cyclonic gyres, forming a powerful jet stream, extending mainly along the continental slope. In summer the intensity of currents weakens, and the circulation becomes less organized, breaking into a number of eddies. The circulation scheme described above, of course, is simplified. The jet of the Rim Current meanders, and a series of anticyclonic eddies located on its periphery are formed. The decisive influence on the variability of the circulation scheme in the upper layer has the wind field variations. Fig. 9 shows the winter-mean and summer-mean values of the wind stress vorticity over the region of the Black Sea in different years. These graphs were obtained on the basis of the ERA-Interim atmospheric reanalysis data, used as the boundary conditions on the sea surface during fulfilling the reanalysis.

Wind stress vorticity almost always has a positive value for both winter and summer. The exception for the summer period is a few years, when there were negative values observed. In winter the negative vorticity was monitored only in 2000, besides, in 1997, it was close to zero. Another feature is that the vorticity of the wind field in winter is higher than in summer. The mean value for the entire considered winter period 3.5 times exceeds the summer one. But there are 
exceptions. Summer wind stress vorticity value in 1997 and in 1999 - 2002 was higher than the winter one. Such fluctuations of the wind stress vorticity values lead to different circulation modes of the Black Sea upper layer. Fig. 10 and 11 demonstrate the maps of winter-mean and summer-mean currents in the upper $30 \mathrm{~m}$ layer of the sea. The top row in the both figures corresponds to the years when in the considered season the maximum wind stress vorticity values have been observed, the bottom one - when the minimum values have been observed (see Fig. 9). The pattern of winter circulation in 1996 and 2010 is consistent with the winter circulation in the Black Sea, a key element of which is the Rim Current; in 1997 and 2000 the circulation consisted of separate eddies and was more like the summer one (Fig. 10). A similar situation is observed in Fig. 11. In 2002 and 2005 the main element of the summer circulation was the basin-scaled cyclonic gyre. In 1993 and 1998, respectively, there was typical for the summer season circulation, with a set of eddies prevailing and the pronounced large-scale current lacking. Atypical modes of the Black Sea upper layer circulation are also observed on numerous satellite images. It is worth noting that assimilation of satellite altimetry data in the model when performing reanalysis provided an opportunity to get a real picture of the currents.

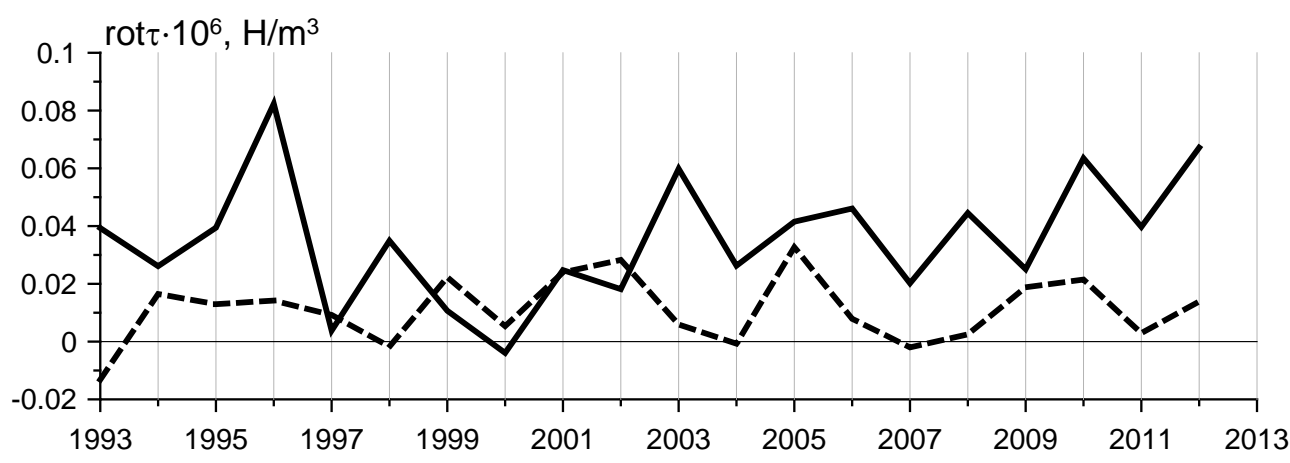

Fig. 9. The graphs of the changes of winter-mean and summer-mean values of the wind stress vorticity (solid line corresponds to the winter values, the dashed - to the summer ones)

In addition to horizontal currents, the vertical movements play an important role in the circulation of the Black Sea waters. According to the modeling vertical velocity fields at various depths show the checkered picture where the areas with the velocity of one sign are interspersed with areas with the velocity of the other sign. It is caused by various types of synoptic processes: eddies, the Rossby waves, as well as, the heterogeneity and non-stationarity of the wind field. Near the coast there are rather high vertical velocities, caused by topographic effects on the continental slope. However, the mean vertical circulation is determined by the overall positive vorticity of the currents in the Black Sea. In the center of the basin in its deep part the water rises to the surface, near the surface then moves towards the shore, and falls down. 

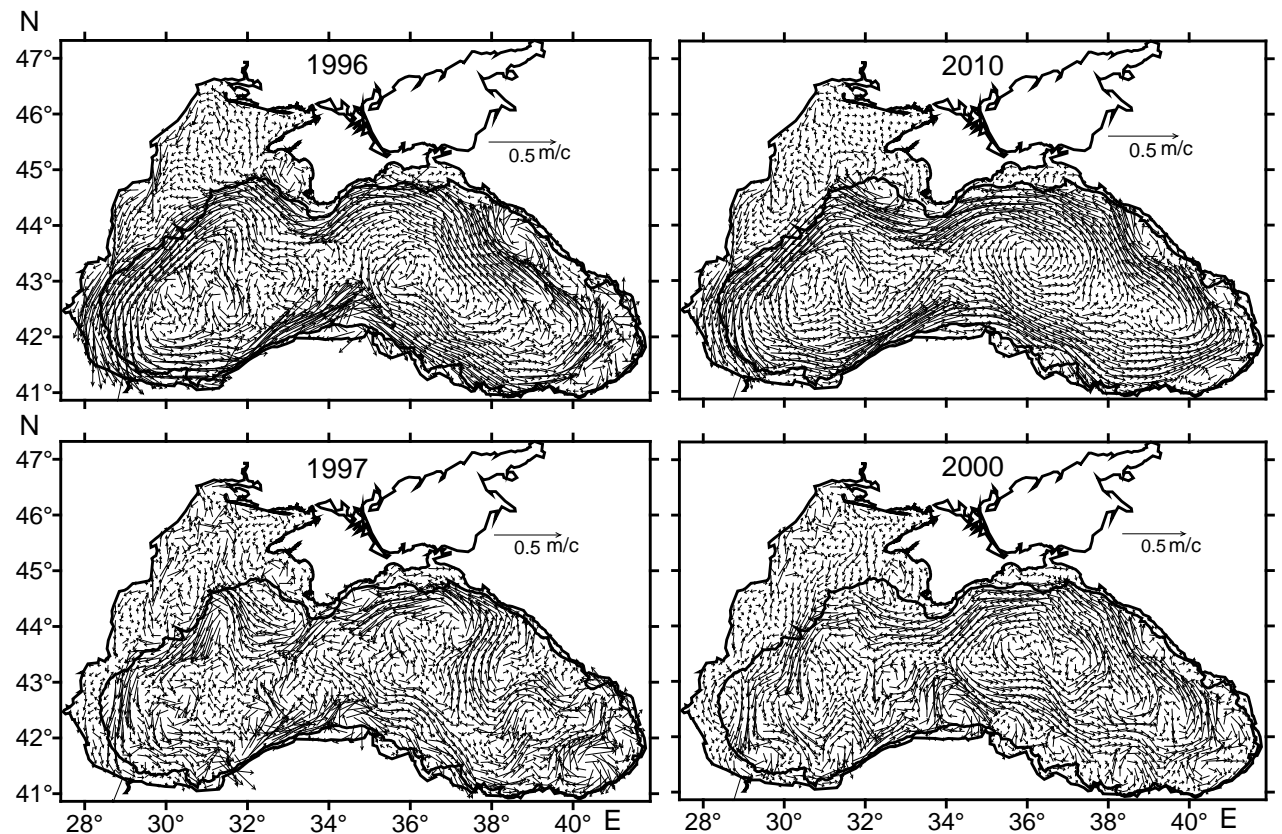

Fig. 10. The maps of the winter-mean currents in the upper $30 \mathrm{~m}$ layer of the Black Sea (the top row corresponds to the years when in the considered season the maximum wind stress vorticity values have been observed, the bottom one - when the minimum values have been observed)
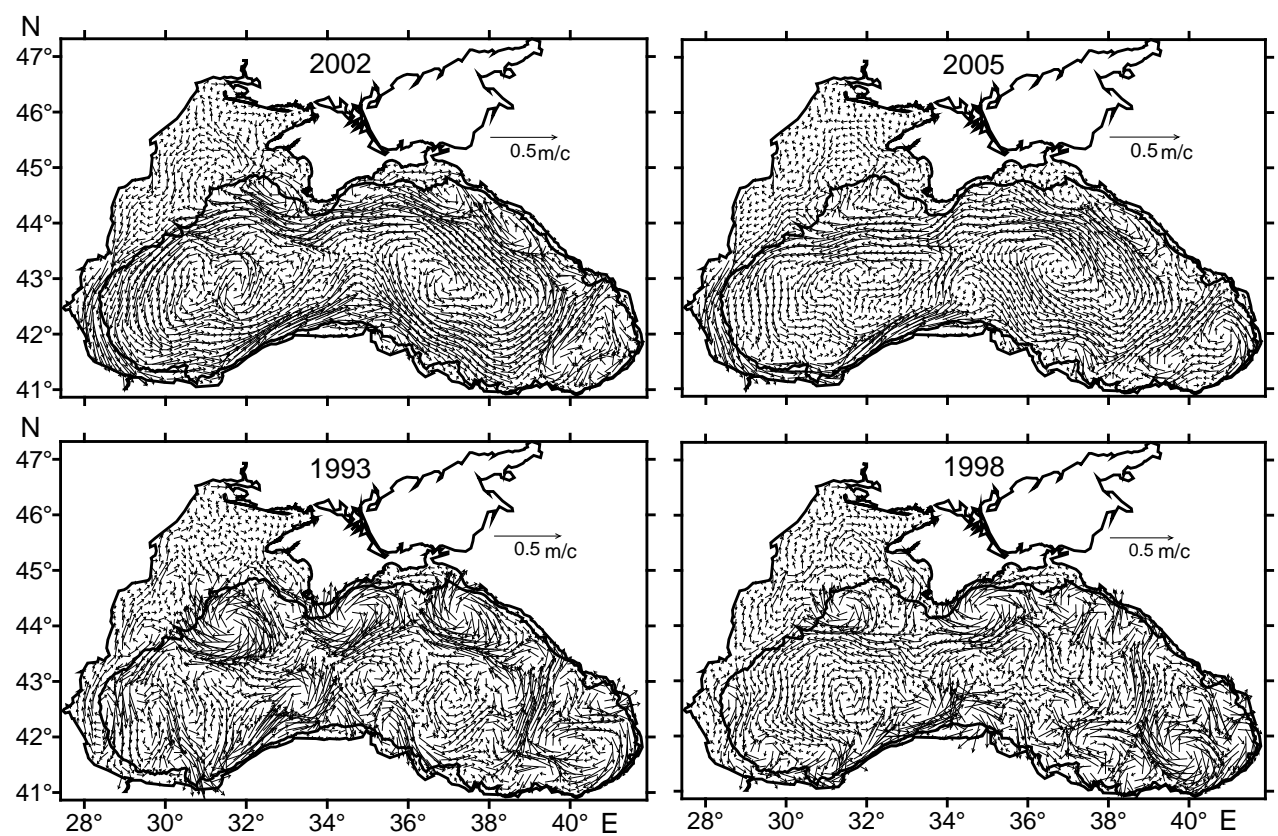

Fig. 11. The maps of the summer-mean currents in the upper $30 \mathrm{~m}$ layer of the Black Sea (the top row corresponds to the years when in the considered season the maximum wind stress vorticity values have been observed, the bottom one - when the minimum values have been observed)

PHYSICAL OCEANOGRAPHY NO. 1 (2016) 
Fig. 12 shows the mean vertical velocity profiles for the deep part of the basin (below $1000 \mathrm{~m}$ ) and the rest part located above the continental slope and shelf (for horizons up to $225 \mathrm{~m}$ ). Profiles were obtained by averaging over the area bounded by the $1000 \mathrm{~m}$ isobath, and over the time for the entire considered period. In the deep part of the basin the water on average rises and in a coastal area falls in accordance with the scheme described above. The mean vertical velocity in the central part of the surface increases to $27.5 \mathrm{~m}$ horizon, then falls down near zero at the sea surface. The vertical velocity growth in a layer up to $27.5 \mathrm{~m}$ should be accompanied by the inflow of water through the lateral surface of the cylinder, with the base bounded by $1000 \mathrm{~m}$ isobath, and the top layer (from 27.5 to $0 \mathrm{~m}$ ), where the vertical velocity falls, outflow of water through a lateral boundary of this area must be observed. This behavior is confirmed by the profile of the specific mass flow through the lateral surface of the cylinder as shown in the graph in Fig. 12, c. This profile was obtained by applying the fields of the horizontal currents velocity from the reanalysis. In accordance with the behavior of the vertical velocity profile the direction of the specific mass flow through a lateral surface changes from negative (i.e. into the deep-water part) to the positive one.

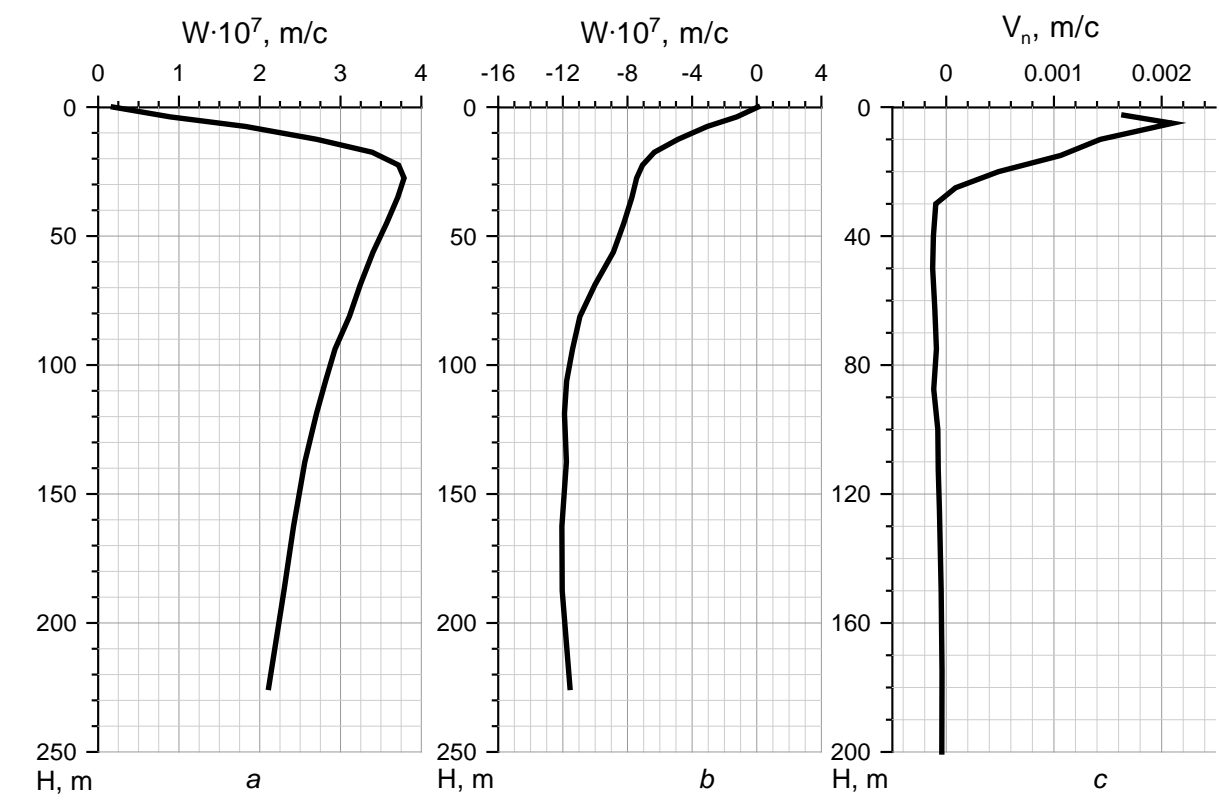

Fig. 12. Profiles of the vertical velocity $W$ time-averaged over the whole considered period inside the area, bounded by $1000 \mathrm{~m}$ isobath $(a)$ and outside this area $(\sigma)$, and also the specific mass flow profile through the lateral surface of the cylinder bounded by $1000 \mathrm{~m}$ isobath $(c)$

Maximum value of the vertical velocity at $27.5 \mathrm{~m}$ depth (Fig. 12, a) is consistent with the value of the velocity at the lower boundary of the Ekman boundary layer, which is defined by the formula $W_{E}=\operatorname{rot}_{z} \tau /(\rho f)$, where $\tau$ is wind stress, $f$ is the Coriolis parameter, $\rho$ is the density of seawater. Applying the values of wind parameters used in the reanalysis, according to this formula we obtain the mean velocity value for the entire period, equal to $4.5 \times 10^{-7} \mathrm{~m} / \mathrm{s}$, which is 
not much different from the maximum value on the profile in Fig. 12, and which has been computed according to the reanalysis data.

It is also possible to compare the amount of water entering the Ekman layer ( $27.5 \mathrm{~m}$ above the horizon) from the deep layers through the section of the cylinder bounded by $1000 \mathrm{~m}$ isobath, and also through its lateral surface. For the first value, we obtained, using a vertical velocities, the value of $1.0 \times 105 \mathrm{~m}^{3} / \mathrm{s}$, and for the second one, using a horizontal velocities, $-1.02 \times 105 \mathrm{~m}^{3} / \mathrm{s}$. These numbers are almost identical, which confirms correctness of the aforementioned evaluations.

The interannual variability of the mean maximum of the vertical velocity in the deep part of the sea is shown in Fig. 13. In the same figure the triangles mark the values of the velocity $W_{E}$ at the lower boundary of the Ekman layer, obtained from the wind stress values applied in reanalysis. The dashed line shows the annual-averaged flow of the mass in the Ekman layer, directed from the deep part of the sea. The values of the velocity $W_{E}$ are consistent with the values of the maxima of the vertical velocity quite well (especially since 2006), computed according to the reanalysis results. This confirms the validity of the identification of the maximum of the vertical velocity on the profile for the deep part of the sea at the Ekman velocity, and the depth of the location of the maximum at the depth of the Ekman layer. Thus, we can conclude that the action of the wind makes the main contribution to formation of the vertical circulation cell in the upper layer of the Black Sea.

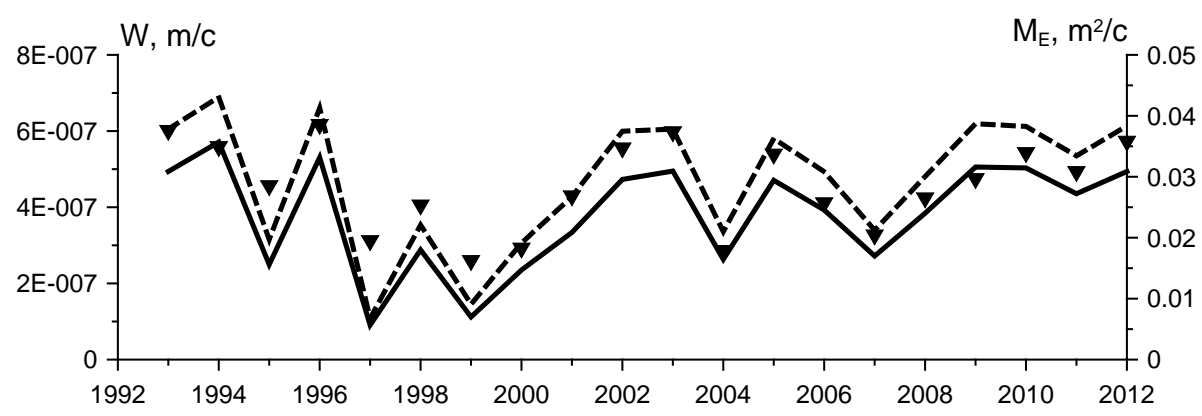

Fig. 13. Change of the maximums of the annual-mean values of the vertical velocity $W$ for 1993 2012 period (solid line) and correspondent values of the Ekman velocity $W_{E}$ (triangles), computed according to wind stress and also annual-mean water transport $M_{E}$ from the interior part of the basin in the Ekman layer (dashed line)

\section{Conclusion}

The analysis of the Black Sea hydrophysical fields within 1993 - 2012 period is performed in the present article. The fields were resulted from physical reanalysis carried out based on remote sensing data assimilation in the numerical model of the Black Sea circulation.

In accordance with the performed modeling in course of the period under consideration the upper layer temperature and salinity of the Black Sea grow; it is manifested in increase of the sea surface temperature and degradation of the cold 
intermediate layer. Increase of the temperature of the sea upper layer was accompanied by an increase of salinity.

Availability of three-dimensional hydrophysical arrays on a regular grid permits to quantify the impact of various physical processes on formation of the thermohaline structure of the Black Sea waters and its circulation. In particular, impact of winter thermal convection and water advection from the north-western shelf upon renewal of the cold intermediate layer waters is quantitatively assessed. It is shown that the main role in the CIL water renewal belongs to the winter convection, although in some years the contributions of these two processes have been almost equal.

Analysis of currents in the upper $30 \mathrm{~m}$ layer showed that formation of a horizontal circulation was conditioned mainly by the wind stress vorticity over the Black Sea. According to the ERA-Interim reanalysis data, the average wind stress vorticity value for the entire considered winter period 3.5 times exceeds the summer one. This fact largely determines the nature of circulation in winter and summer, in winter the main component of the Black Sea circulation is the Rim Current, and in summer it is dominated with a set of eddies prevailing and the pronounced large-scale current lacking. However, in those years when the winter wind vorticity fields were low, the surface currents circulation is more consistent to the summer one. And, in contrast, in those years when the wind vorticity fields in the summer were high enough, the summer circulation corresponded to a typical winter one, the main element of which is the Rim Current.

It is revealed that a crucial contribution to formation of a vertical circulation cell in the Black Sea is done by the wind field. The water in the deep part of the basin rises to the surface, transferred in the shore direction in the Ekman layer, and there descends.

Acknowledgements. The work was performed within the framework of scientific project "Research of regularities of changes in the state of the marine environment on the basis of operational observations and data of the nowcast, forecast, and reanalysis of state of the sea areas system (Operational Oceanography code), and partly supported by MyOcean2 project (GA 283367) EC FP7/2011-2014. The authors are grateful to V.N. Belokopytov for the preparation of the annual-mean temperature and salinity profiles.

\section{REFERENCES}

1. Knysh, V.V., Kubryakov, A.I. \& Moiseenko, V.A. [et al.], 2008, "Uproshchennyy metod rascheta spektral'nogo diffuznogo koeffitsienta oslableniya sveta $v$ verkhnem sloe Chernogo morya na osnove sputnikovykh dannykh [Tendencies of variability of the Black Sea thermohaline and dynamic parameters, revealed by reanalysis results for 1985-1995 period]”, Ekologicheskaya bezopasnost' pribrezhnoy i shel'fovoy zon i kompleksnoe ispol'zovanie resursov shel'fa, iss. 16, pp. 279-290 (in Russian).

2. Knysh, V.V., Korotaev, G.K. \& Moiseenko, V.A. [et al.], 2011, "Seasonal and interannual variability of Black Sea hydrophysical fields reconstructed from 1971-1993 reanalysis data”, Izvestiya, Atmospheric and Oceanic Physics, vol. 47:399, iss. 3, pp. 433-446.

3. Knysh, V.V., Korotaev, G.K. \& Mizyuk, A.I. [et al.], February 2012, "Assimilation of hydrological observation data for calculating currents in seas and oceans”, Izvestiya, Atmospheric and Oceanic Physics, vol. 48, iss. 1, pp. 57-73. 
4. Dorofeev, V.L., Korotaev, G.K. \& Sukhikh, L.I., 2013, "Study of long-term variations in the Black Sea fields using an interdisciplinary physical and biogeochemical model”, Izvestiya, Atmospheric and Oceanic Physics, vol. 49, iss. 6, pp. 622-631.

5. Dorofeev, V.L. 2009, "Modelirovanie dekadnoy izmenchivosti ekosistemy Chernogo morya [Modeling of decadal variability of the Black Sea ecosystem]”, Morskoy gidrofizicheskiy zhurnal, no. 6, pp. 71-81 (in Russian).

6. Demyshev, S.G., Korotaev, G.K., 1992, "Chislennaya energosbalansirovannaya model" baroklinnykh techeniy okeana s nerovnym dnom na setke $S$ [Numerical energy-balanced model of baroclinic currents in the ocean with bottom topography on the C-grid]", Chislennye modeli i rezul'taty kalibrovochnykh raschetov techeniy v Atlanticheskom okeane, Moscow, IVM RAN, pp. 163-231 (in Russian).

7. Korotaev, G.K., Oguz T. \& Dorofeev, V.L. [et al.], 2011, "Development of Black Sea nowcasting and forecasting system”, Ocean Sci., vol. 7, no. 5, pp. 1-21.

8. Suslin, V.V., Churilova, T.Ya. 2010, "Uproshchennyy metod rascheta spektral'nogo diffuznogo koeffitsienta oslableniya sveta $v$ verkhnem sloe Chernogo morya na osnove sputnikovykh dannykh [Simplified method of calculation of spectral diffuse beam attenuation coefficient in the Black Sea upper layer on the basis of satellite data]", Ekologicheskaya bezopasnost' pribrezhnoy i shel'fovoy zon i kompleksnoe ispol'zovanie resursov shel'fa, iss. 22. pp. 47-60 (in Russian).

9. Dorofeev, V.L., Korotaev, G.K., 2004, “Assimilyatsiya dannykh sputnikovoy al'timetrii v vikhrerazreshayushchey modeli tsirkulyatsii Chernogo morya [Assimilation of the satellite altimetry data in the eddy resolved model of the Black Sea circulation]”, Morskoy gidrofizicheskiy zhurnal, no. 1, pp. 52-68 (in Russian).

10. Ovchinnikov, I.M., Popov, Yu.I., 1984, “ $K$ voprosu o formirovanii kholodnogo promezhutochnogo sloya $v$ Chernom more [On the formation of the cold intermediate layer in the Black Sea]”, Dokl. AN SSSR, vol. 279, no. 4, pp. 986-989 (in Russian).

11. Gertman, I.F. 1991, "Termokhalinnaya struktura vod morya [The thermohaline structure of the sea waters]", Gidrometeorologiya i gidrokhimiya morey SSSR. T. IV. Chernoe more. Vyp. 1. Gidrometeorologicheskie usloviya, St. Petersburg, Gidrometeoizdat, vol. 4, iss. 1, pp. 146195 (in Russian).

12. Oguz, T., Besiktepe, S. 1999, "Observations on the Rim Current structure, CIW formation and transport in the western Black Sea”, Deep-Sea Res., vol. 46, no 10, pp. 1733-1753.

13. Korotaev, G.K., Knysh, V.V. \& Kubryakov, A.I., 2014, "Study of formation process of cold intermediate layer based on reanalysis of Black Sea hydrophysical fields for 1971-1993", Izvestiya, Atmospheric and Oceanic Physics, vol. 50, iss. 1, pp. 35-48.

14. Blatov, A.S., Bulgakov, N.P. \& Ivanov, A.N., [et al.], 1984, "Izmenchivost' gidrofizicheskikh poley Chernogo morya [Variability of the hydrodynamical fields in the Black Sea]", St. Petersburg, Gidrometeoizdat, 240 p. (in Russian). 